\title{
MENUJU MASYARAKAT EKONOMI ASEAN 2015: ASPEK REGIONAL DAN IMPLIKASINYA TERHADAP HUKUM NASIONAL INDONESIA
}

Budi Hermawan Bangun

E-mail: budi_h_bangun79@yahoo.co.id

\begin{abstract}
The enactment of the ASEAN Economic Community by 2015 as one pillars of the ASEAN Community, carrying implications for it member states. As one of ASEAN member, Indonesia should do legal reform-oriented guarantee and legal certainty to carry out the substance of the ASEAN agreements in the field of economics.
\end{abstract}

Keywords: ASEAN Economic Community, regional cooperation, national law.

\begin{abstract}
ABSTRAK
Berlakunya Masyarakat Ekonomi ASEAN pada tahun 2015 sebagai salah satu pilar Komunitas ASEAN, membawa implikasi bagi negara-negara anggotanya. Sebagai salah satu anggota ASEAN, Indonesia harus melakukan pembaharuan hukum yang berorientasi pada jaminan dan kepastian hukum untuk melaksanakansubstansi dari perjanjian-perjanjian ASEAN di bidang ekonomi.
\end{abstract}

Kata kunci: Masyarakat Ekonomi ASEAN, kerjasama regional, hukum nasional

\section{PENDAHULUAN}

Sejak berdirinya hingga saat ini, tidak dapat dipungkiri bahwa ASEAN (Association of Southeast Asian Nation) telah menjadi sebuah organisasi yang signifikan dalam sistem internasional. ASEAN sendiri terbentuk pada tanggal 8 Agustus 1967 di Bangkok, yang ditandatangani oleh lima menteri luar negeri dari lima negara yaitu Adam Malik dari Indonesia, Narcisco R. Ramos dari Filipina, Tun Abdul Razak dari Malaysia, S. Rajaratman dari Singapura, dan Thanat Khoman dari Thailand. Dengan ditandatanganinya ASEAN
Declaration atau lebih dikenal dengan sebutan Bangkok Declaration maka resmilah ASEAN terbentuk.

Lima negara yang menandatangani dokumen yang secara tradisional dikenal sebagai pendiri ASEAN yaitu Indonesia, Filipina, Malaysia, Singapura, dan Thailand sekaligus merupakan negara-negara anggota pertama dari organisasi regional tersebut. Bertahap seiring berjalannya waktu dan semakin solidnya ASEAN, satu persatu negara-negara di kawasan Asia Tenggara bergabung dalam waktu yang tidak bersamaan. 
Dimulai dari Brunei Darussalam pada tanggal 8 Januari 1984, Vietnam pada 28 Juli 1995, Laos dan Myanmar pada 23 Juli 1997, dan Kamboja pada 30 April 1999. Beberapa tahun terakhir Timor Leste juga sudah mulai mempertimbangkan usulan keanggotaannya di ASEAN.

Sebenarnya ASEAN adalah organisasi regional tertutup karena keanggotaannya hanya terdiri dari negara-negara Asia Tenggara. ${ }^{1}$ Pendirian ASEAN dilatarbelakangi oleh ketidakstabilan ekonomi dan persamaan nasib negara-negara Asia Tenggara yang hampir semuanya mengalami penjajahan (kecuali Thailand). Pendirian ASEAN memiliki tujuan yang mulia yakni sebagai badan kerjasama dibidang ekonomi, politik, sosial budaya untuk menciptakan stabilitas dan kedamaian di kawasan Asia Tenggara berdasarkan Piagam PBB (UN Charter).

Dalam dokumen "Deklarasi Bangkok" yang hanya terdiri dari lima pasal dinyatakan tujuan terbentuknya organisasi regional tersebut. Meskipun tidak dapat dipungkiri begitu pentingnya "Deklarasi Bangkok" bagi eksistensi ASEAN, namun harus diakui jika dokumen itu tidak dapat menjadikan ASEAN sebagai perkumpulan atau organisasi formalyang diterima sistem internasional. Alasannya adalah bahwa dokumen itu bukanlah bentuk perjanjian yang mengikat, dalam artian tidak adanya ratifikasi

\footnotetext{
1 Sumaryo Suryokusumo, "Aspek Hukum Internasional dan Regional ASEAN Sehubungan Dengan AFTA", Jurnal Luar Negeri, No. 24 Tahun 1993, hlm. 38.
} Budi Hermawan Bangun, Menuju Masyarakat Ekonomi ASEAN 2015: Aspek Regional dan Implikasinya terhadap Hukum Nasional Indonesia sebagaimana bentuk perjanjian internasional lazimnya.

Salah satu perjanjian terpenting dalam perjalanan ASEAN adalah Treaty of Amity and Coorperation (TAC) yang disepakati dan secara hukum mengikat negara-negara anggota ASEAN sembilan tahun sejak ASEAN terbentuk, atau tepatnya pada 24 Februari 1976 di Bali. ${ }^{2}$ TAC menjadi penting karena melalui traktat ini terbentuk sebuah mekanisme khas dalam penyelesaian sengketa antara negara-negara anggota ASEAN yang lazim dikenal sebagai "ASEAN Way". ASEAN Way adalah cara ASEAN mengatasi berbagai masalah baik internal maupun eksternal organisasi melalui consultation and consensus. ${ }^{3}$ Adapun prinsip yang sama antara ASEAN Way dengan TAC yaitu menghormati kedaulatan setiap negara anggota, prinsip noninterference, penyelesaian masalah dengan cara damai, dan tidak menggunakan cara-cara yang mengandung unsur pemaksaan. ${ }^{4}$ Dalam mengaplikasikan prinsip ini sangat sulit bagi ASEAN untuk melakukan kerjasama dengan unsur-unsur yang dapat memaksa negara anggotanya. $\mathrm{Hal}$ ini menyebabkan ASEAN tidak mampu berbuat banyak untuk menghadapi konflik internal ASEAN karena

${ }^{2}$ Hilton Tanaka Putra dan Eka An Aqimuddin, Mekanisme Penyelesaian Sengketa di ASEAN: Lembaga dan Proses, Yogyakarta: Graha Ilmu, 2011, hlm. 43.

${ }^{3}$ Gillian Goh, "The 'ASEAN Way': Non-Intervention and ASEAN's Role in Conflict Management", Stanford Journal of East Asian Affairs, Vol. 3 No. 1, (Spring 2003), hlm. 114. ${ }^{4}$ Ibid 
terhalang oleh prinsip noninterference. ${ }^{5}$

Pada KTT ASEAN ke-13 di Singapura tahun 2007 silam yang juga bertepatan dengan ulang tahunnya ke-40, dengan ditandatanganinya piagam ASEAN dan blue print ASEAN menuju Masyarakat Ekonomi ASEAN 2015, kerjasama regional ASEAN telah menemukan bentuk yang lebih riil lagi. Sepuluh negara ASEAN berusaha dalam membentuk identitas tunggal kawasan, meskipun berbagai perbedaaan masing-masing negara anggota masih membayangi perjalanan ini. Dengan kata lain, ASEAN telah melalui proses transformasi, yang dulunya hanya sebatas kumpulan negara yang berbicara tentang politik guna mencapai kedamaian dan keamanan di Asia Tenggara kini berhaluan menuju kearah komunitas kawasan yang lebih terintergrasi. Cita-cita integrasi ASEAN kini lebih jelas setelah para kepala negara menetapkan komunitas ASEAN (ASEAN Community) yang tercantum dalam Bali Concord II yang didasarkan atas tiga pilar, yaitu Komunitas Politik Keamanan ASEAN (APSC), Komunitas Ekonomi ASEAN (MEA) dan Komunitas Sosial Budaya ASEAN (ASCC). Namun dalam perjalanannya, MEA adalah tujuan akhir dari keinginan berintegrasi di Asia Tenggara.

Piagam ASEAN (ASEAN Charter) adalah payung hukum yang

5 Eddy Pratomo, "Prospek dan Tantangan Hukum Internasional di ASEAN dan Indonesia Pasca Piagam ASEAN dari Sisi Perjanjian Internasional", Jurnal Hukum No. 1 Vol. 16, Januari 2009, hlm. 63.

Budi Hermawan Bangun, Menuju Masyarakat Ekonomi ASEAN 2015: Aspek Regional dan Implikasinya terhadap Hukum Nasional Indonesia diharapkan untuk menghadapi arus globalisasi. Selain itu, piagam ini juga mengharapkan ASEAN semakin kokoh dan solid dalam menghadapi berbagai perubahan di dunia internasional. Perumusan ASEAN Charter didahului dengan pembentukan Eminent Person Group (EPG) yang berfungsi sebagai perumus landasan hukum organisasi regional ini. 6 Dengan ASEAN Charter diyakini jika organisasi ini akan menjadi sebuah komunitas ASEAN dengan terbentuknya komunitas politik dan keamanan, ekonomi, dan sosial budaya pada tahun 2015 .

Salah satu wujud komunitas ASEAN adalah terciptanya integrasi ekonomi melalui Masyarakat Ekonomi ASEAN (MEA). Pada umumnya integrasi ekonomi ini dimaksudkan untuk menciptakan ekonomi ASEAN yang stabil, makmur, dan kompetitif di mana terjadi aliran-aliran bebas barang, layanan, investasi, dan aliran kapital, pembangunan ekonomi yang adil dan pengurangan kemiskinan dan disparitas sosioekonomi.7 Untuk mengintegrasikan ekonomi dalam rangka menciptakan sebuah area ekonomi yang kuat dibutuhkan komitmen yang lebih besar dari negara anggota dalam rangka menciptakan sebuah area ekonomi yang kuat.

Sebelum MEA,t elah ada AFTA (ASEAN Free Trade Area) yaitu sebuah rezim kesepakatan untuk

${ }^{6}$ Ibid, hlm. 62.

${ }^{7}$ Soesastro dalam Budi Winarno."Politik Regionalisme dan Tantangan ASEAN di Tengah Arus Besar Globalisasi”, Jurnal Ilmu Politik Hubungan Internasional Spektrum, Vol. 5, No. 2, Juni 2008, hlm. 4. 
membentuk kawasan perdagangan bebas di Asia Tenggara. yang harapannya dapat memperkuat posisi ASEAN dalam mengintegrasikan diri ke dalam perdagangan global. ${ }^{8}$

AFTA merupakan suatu kawasan dimana tarif dan kuota antara negara anggota dihapuskan, namun masing-masing negara masih menerapkan tarif mereka masing-masing terhadap negara bukan anggota. Sebenarnya AFTA sendiri telah dimulai sejak dicapai kesepakatan pada tahun 1992 oleh negara-negara anggota ASEAN namun implementasinya baru terlaksana pada Januari 2003. Salah satu faktor pendukung AFTA adalah kemampuan ASEAN sebagai salah satu institusi regional untuk memperlihatkan kekompakan menciptakan keamanan regional yang merupakan salah satu prasyarat utama dalam menciptakan stabilitas kerjasama ekonomi baginegara anggota AFTA.

Pembentukan AFTA sendiri merupakan langkah awal dalam rangka mendukung proses terciptanya MEA. Konsep utama mekanisme kerja dari AFTA adalah:

1. Penurunan hambatan tarif perdagangan untuk sejumlah produk bagi negara anggota ASEAN.

2. Liberalisasi dalam semua bidang termasuk menghilangkan segala hambatan non tarif.

3. Penurunan hambatan untuk akses pasar di sektor jasa bagi negara anggota ASEAN.

Pembentukan MEA juga merupakan salah satu pilar pendukung fondasi terciptanya ekonomi ASEAN 2015. Salah satu alasan logis terbentuknya komunitas ekonomi ini, disebabkan oleh keadaan yang selama ini menggambarkan kelemahan institusi ASEAN. Institusi ini tidak cukup memiliki kewenangan atau otoritas dalam menentukan berbagai masalah kebijakan ekonomi yang justru sangat diperlukan saat ini. Hambatan yang dihadapi oleh ASEAN sendiri juga datang dari perbedaan-perbedaan yang terjadi dalam inter-regional ASEAN juga turut menyumbang bagi kurang padunya kerjasama kawasan ini dalam menopang ASEAN sebagai kekuatan yang layak diperhitungkan dalam ekonomi-politik global. ${ }^{9}$

Dapat dikatakan bahwa pemikiran akan pentingnya menjalin kerjasama yang lebih erat lagi dalam proses integrasi merupakan salah satu upaya merespon tantangan di era globalisasi karena dengan kerjasama yang kuat dan intensif di bidang ekonomi maka ASEAN akan mampu memegang kendali paling tidak di kawasannya sendiri.

Dengan adanya integrasi di bidang ekonomi dalam kerangka ASEAN, maka Indonesia sebagai salah satu pendiri dan anggota ASEAN juga terikat dengan berbagai ketentuan yang diatur oleh perjanjian-perjanjian kerjasama bidang ekonomi ASEAN tersebut. Dengan demikian terdapat berbagai implikasi dari berbagai perjanjian tersebut terhadap hukum nasional Indonesia.

8Ibid, hlm. 4-5.

${ }^{9}$ Ibid, hlm. 5.

Budi Hermawan Bangun, Menuju Masyarakat Ekonomi ASEAN 2015: Aspek Regional dan Implikasinya terhadap Hukum Nasional Indonesia 
Tulisan ini bermaksud untuk memaparkan berbagai perjanjianperjanjian dalam kerangka ASEAN di bidang ekonomi dan implikasi dari perjanjian-perjanjian tersebut dalam hukum nasional Indonesia.

\section{PEMBAHASAN}

\section{Perkembangan ASEAN: Dari Asosiasi Menuju Komunitas}

Kawasan Asia Tenggara yang secara geopolitik dan geoekonomi mempunyai nilai strategis, menjadi incaran bahkan pertentangan kepentingan negara-negara besar paska Perang Dunia II. Persaingan antar negara adidaya dan kekuatan besar lainnya di kawasan antara lain terlihat pada Perang Vietnam. Disamping itu, konflik kepentingan juga pernah terjadi diantara sesama negara-negara Asia Tenggara seperti "konfrontasi" antara Indonesia dan Malaysia, klaim teritorial antara Malaysia dan Filipina atas Sabah dan berpisahnya Singapura dari Federasi Malaysia. ${ }^{10}$

Dilatarbelakangi perkembangan situasi di kawasan pada saat itu, negara-negara Asia Tenggara menyadari perlunya dibentuk suatu kerjasama yang dapat meredakan saling curiga sekaligus membangun rasa saling percaya serta mendorong pembangunan di kawasan. Sebelum terbentuknya ASEAN tahun 1967, negara-negara Asia Tenggara telah melakukan berbagai upaya untuk menggalang kerjasama regional baik yang bersifat intra maupun ekstra kawasan seperti Association of

10 Frank Frost, 2008, "ASEAN's Regional Cooperation and Multilateral Relations: Recent Development and Australia's Interests", Australian Parliament Research Paper, hlm. 4.
Southeast Asia (ASA), Malaya, Philippina, Indonesia (MAPHILINDO), South East Asian Ministers of Education Organization (SEAMEO), South East Asia Treaty Organization (SEATO) dan Asia and Pacific Council (ASPAC). Namun atas berbagai alasan, bentuk-bentuk kerjasama regional ini mengalami kegagalan. ${ }^{11}$

Meredanya rasa saling curiga diantara negara-negara Asia Tenggara membawa dampak positif yang mendorong pembentukan organisasi kerjasama kawasan. Pertemuan-pertemuan konsultatif yang dilakukan secara intensif antara para Menteri Luar Negeri Indonesia, Malaysia, Filipina, Singapura dan Thailand menghasilkan rancangan Joint Declaration, yang antara lain mencakup kesadaran perlunya meningkatkan saling pengertian untuk hidup bertetangga secara baik serta membina kerjasama yang bermanfaat diantara negara-negara yang sudah terikat oleh pertalian sejarah dan budaya.

Selanjutnya pada tanggal 8 Agustus 1967 di Bangkok, lima wakil negara di Asia Tenggara, yaitu: Wakil Perdana Menteri merangkap Menteri Luar Negeri

${ }^{11}$ ASA dan Maphilindo berakhir akibat konflik antar sesama negara anggota, yaitu Malaysia dan Filipina yang mengakhiri ASA, dan konfrontasi Indonesia terhadap Malaysia yang dilancarkan oleh Presiden Soekarno menyebabkan berakhirnya Maphilindo. Sedangkan SEATO menjadi tidak efektif karena sejak awalnya kerjasama ini merupakan inisiasi dari luar Asia Tenggara, yaitu Amerika Serikat, dengan agenda untuk membendung pengaruh komunis di kawasan Asia Tenggara. 
Malaysia dan para Menteri Luar Negeri Indonesia, Filipina, Singapura dan Thailand menandatangani Deklarasi ASEAN atau Deklarasi Bangkok. Deklarasi tersebut menandai berdirinya suatu organisasi regional yang diberi nama Association of Southeast Asian Nations/ASEAN

(Perhimpunan Bangsa-Bangsa Asia Tenggara). Organisasi ini bertujuan meningkatkan pertumbuhan ekonomi, kemajuan sosial, dan pengembangan kebudayaan negaranegara anggotanya, serta memajukan perdamaian di tingkat regional yang masih pada tahap kooperatif dan belum bersifat integratif. 12

Kegagalan dari berbagai kerjasama regional di kawasan Asia Tenggara sebelumnya menyebabkan ASEAN pada mulanya merupakan sebuah organisasi yang longgar. Hal ini nampak dari pemilihan bentuk Deklarasi sebagai instrumen pembentukan ASEAN dan pemilihan nama "Asosiasi" (Association) atau perkumpulan. Hal ini menyebabkan seringkali timbul kesalahpahaman bahwa ASEAN bukanlah sebuah organisasi internasional, melainkan hanya sebuah forum perkumpulan para pemimpin negara-negara di kawasan Asia Tenggara. ${ }^{13}$ Harus diakui bahwa pendapat ini tidak sepenuhnya keliru karena awalnya ASEAN tidak didesain sebagai sebuah organisasi supranasional. Mantan Sekretaris Jenderal ASEAN, Rodolfo Severino Jr., misalnya pernah menyatakan bahwa: "ASEAN's founders in 1967 intended ASEAN to be an association of all states of

${ }^{12}$ Lihat ASEAN Declaration

(Bangkok Declaration) 1967.

13Hilton dan Eka,op. cit., hlm. 26.
Southeast Asia cooperating voluntary for the common good, with peace and economic, social and cultural development its primary purposes. ASEAN is not and was not meant to be a supranational entity acting independently of its members. It has no regional parliament or council of ministers with lawmaking powers, no power of enforcement, no judicial system."14

Seiring dengan perkembangan ASEAN, bentuk kerjasama tidak hanya dibatasi pada bidang ekonomi, sosial dan budaya semata, tetapi mulai merambah pada bidang politik. Pembentukan Zone of Peace, Freedom and Neutrality Declaration (ZOPFAN) pada tahun 1971 dan yang lebih signifikan adalah Treatyof Amity and Cooperation (qzTAC) pada tahun 1976 merupakan langkah awal yang membuat ASEAN mulai bergerak dari sekedar perkumpulan ke arah organisasi internasional dalam arti yang sebenarnya ${ }^{15}$.

Langkah ini kemudian turut diperkuat dengan proses perluasan keanggotaan yang sekaligus menunjukan bahwa negara-negara lain di kawasan Asia Tenggara (selain kelima negara pendiri) menerima dan merasakan pentingnya kehadiran ASEAN

14 Rodolfo C. Severino Jr., "Asia Policy Lecture: What ASEAN Is and What It Stands For", dalam Rodolfo C. Soverino, Jr., ASEAN: Today and Tomorrow, Jakarta: ASEAN Secretariat, 2002, hlm. 13.

15 Bambang Cipto, Hubungan Internasional di Asia Tenggara, Yogyakarta: Pustaka Pelajar, 2007, hlm. 23. 
sebagai satu-satunya wadah yang dapat menaungi kepentingan mereka, khususnya yang menyangkut kepentingan kawasan.16Proses perluasan keanggotaan ASEAN hingga tercapainya ASEAN-10 terpenuhi dengan diterimanya Kamboja sebagai anggota penuh ASEAN pada upacara penerimaan resmi di Hanoi tanggal 30 April 1999.

Dengan diterimanya Kamboja, maka cita-cita para pendiri ASEAN untuk mewujudkan ASEAN yang mencakup sepuluh negara Asia Tenggara (visi ASEAN-10) telah tercapai.

Menjelang abad ke-21, ASEAN menyepakati untuk mengembangkan suatu kawasan yang terintegrasi dengan membentuk suatu komunitas negara-negara Asia Tenggara yang terbuka, damai, stabil dan sejahtera, saling peduli, diikat bersama dalam kemitraan yang dinamis di tahun 2020. Harapan tersebut dituangkan dalam Visi ASEAN 2020 di Kuala Lumpur tahun 1997. Untuk merealisasikan harapan tersebut, ASEAN mengesahkan Bali Concord II pada KTT ke-9 ASEAN di Bali tahun 2003 yang menyetujui pembentukan

16 Berbagai kekhawatiran sebenarnya muncul berkaitan dengan agenda perluasan ASEAN, terutama kekhawatiran akan terjadinya proses "dilution", atau mencairnya soliditas ASEAN. Namun kekhawatiran ini akhirnya ditepis dengan harapan besar untuk menjadikan ASEAN sebagai organisasi regional dalam arti yang sebenarnya dan kenyataan bahwa sejak penarikan pasukan Vietnam dari Kamboja pada bulan September 1989, praktis sudah tidak ada lagi ganjalanganjalan yang fundamental untuk melakukan perluasan ASEAN.

Budi Hermawan Bangun, Menuju Masyarakat Ekonomi ASEAN 2015: Aspek Regional dan Implikasinya terhadap Hukum Nasional Indonesia
Komunitas

ASEAN(ASEAN

Community). Komunitas ASEAN tersebut terdiri atas 3 (tiga) pilar yaitu Komunitas Politik-Keamanan ASEAN(ASEAN Political-Security Community/APSC), Komunitas Ekonomi ASEAN (ASEAN Economic Community/AEC) dan Komunitas Sosial-Budaya ASEAN (ASEAN Socio-Cultural Community/ASCC). ${ }^{17}$ Indonesia menjadi penggagas pembentukan ASC dan memainkan peran penting dalam perumusan dua pilar lainnya.

KTT ke-10 ASEAN di Vientiane, Laos, tahun 2004, menandai kemajuan konsep Komunitas ASEAN dengan disetujuinya tiga Rencana Aksi (Plan of Action/PoA) untuk masing-masing pilar yang merupakan program jangka panjang untuk merealisasikan konsep Komunitas ASEAN. KTT ke-10 ASEAN juga mengintegrasikan ketiga Rencana Aksi Komunitas ASEAN ke dalam Vientiane Action Programme (VAP) sebagai landasan program jangka pendek-menengah untuk periode 2004-2010. Langkah menuju perwujudan Komunitas ASEAN semakin diperkuat dengan ditandatanganinya "Cebu Declaration on the Acceleration of the Establishment of an ASEAN Community by 2015" oleh para pemimpin ASEAN pada KTT ke-12 ASEAN di Cebu, Filipina, 13 Januari 2007 yang menyepakati percepatan pembentukan Komunitas ASEAN dari tahun 2020 menjadi tahun 2015.

\begin{tabular}{lcr}
\multicolumn{1}{c}{ Seiring } & dengan & upaya \\
perwujudan & Komunitas & ASEAN, \\
ASEAN & menyepakati & untuk \\
menyusun & semacam & konstitusi
\end{tabular}

${ }^{17} \mathrm{Ibid}$, hlm. 80-82. 
yang akan menjadi landasan dalam penguatan kerjasamanya. Dalam kaitan ini, proses penyusunan Piagam ASEAN dimulai sejak tahun 2006 melalui pembentukan Eminent Persons Group dan kemudian dilanjutkan oleh High Level Task Force untuk melakukan negosiasi terhadap draft Piagam ASEAN pada tahun 2007.

Bertepatan dengan 40 tahun terbentuknya ASEAN, dalam KTT-13 ASEAN di Singapura pada Agustus 2007, penandatanganan Piagam ASEAN (ASEAN Charter) menandai perubahanASEAN dari suatu asosiasi longgar menjadi rule-based organisation dan mempunyai legal personality. 18

Dalam rangka mencapai komunitas ASEAN 2015, ASEAN juga menyusun cetak biru (blueprint) dari ketiga pilar komunitas politik keamanan, ekonomi, dan sosial budaya, yang merupakan program aksi untuk memperkuat kerjasamanya.

\section{Berbagai Kerangka Hukum Kerjasama Ekonomi ASEAN}

Sejak dibentuknya ASEAN sebagai organisasi regional pada tahun 1967, negara-negara anggota telah meletakkan kerjasama ekonomi sebagai salah satu agenda utama untuk dikembangkan. Awalnya, kerjasama ekonomi difokuskan pada program-program pemberian preferensi perdagangan (preferential trade), usaha patungan (joint ventures), dan skema saling melengkapi (complementation scheme) antar pemerintah negaranegara anggota maupun pihak swasta di kawasan ASEAN, seperti

29.
ASEAN Industrial Projects Plan (1976), Preferential Trading Arrangement (1977), ASEAN Industrial Complementation scheme (1981), ASEAN Industrial JointVentures scheme (1983), dan Enhanced Preferential Trading arrangement (1987). ${ }^{19}$

Pada dekade 80-an dan 90-an, ketika negara-negara di berbagai belahan dunia mulai melakukan upaya-upaya untuk menghilangkan hambatan-hambatan ekonomi, negara-negara anggota ASEAN menyadari bahwa cara terbaik untuk bekerjasama adalah dengan saling membuka perekonomian mereka, guna menciptakan integrasi ekonomi kawasan.

Pada KTT ke-5 ASEAN di Singapura tahun 1992 telah ditandatangani Framework Agreement on Enhancing ASEAN Economic Cooperation sekaligus menandai dicanangkannya ASEAN Free Trade Area (AFTA) pada tanggal 1 Januari 1993 dengan Common Effective Preferential Tariff (CEPT) sebagai mekanisme utama. Pendirian AFTA memberikan impikasi dalam bentuk pengurangan dan eliminasi tarif, penghapusan hambatan-hambatan non-tarif, dan perbaikan terhadap kebijakan-kebijakan fasilitasi perdagangan. ${ }^{20}$ Dalam perkembangannya, AFTA tidak hanya difokuskan pada liberalisasi perdagangan barang, tetapi juga perdagangan jasa dan investasi.Kesepakatan yang cukup

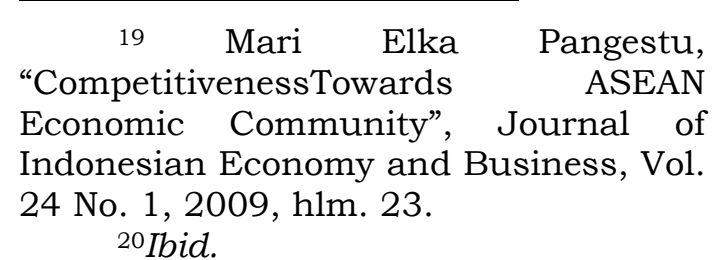
${ }^{20}$ Ibid.

Budi Hermawan Bangun, Menuju Masyarakat Ekonomi ASEAN 2015: Aspek Regional dan Implikasinya terhadap Hukum Nasional Indonesia 
menonjol ini juga merupakan cikal bakal dari visi pembentukan MEA. ${ }^{21}$

KTT ke-9 ASEAN di Bali tahun 2003 menyepakati pembentukan komunitas ASEAN yang salah satu pilarnya adalah MEA. MEA bertujuan untuk menciptakan pasar tunggal dan basis produksi yang ditandai dengan bebasnya aliran barang, jasa, investasi, tenaga kerja terampil dan perpindahan barang modal secara lebih bebas.Setahun berikutnya, dalam KTT ke-10 ASEAN di Vientiene tahun 2004 disepakati Vientiane Action Program (VAP) yang merupakan panduan untuk mendukung implementasi pencapaian MEA. Sementara itu melalui ASEAN Economic Ministers Meeting (AEM) di Kuala Lumpur pada bulan Agustus 2006, disetujui pembuatan suatu cetak biru (blueprint) untuk menindaklanjuti pembentukan MEA dengan mengindentifikasi sifat-sifat dan elemen-elemen MEA pada tahun 2015 yang konsisten dengan Bali Concord II dan dengan target-target dan timelines yang jelas serta preagreed flexibility untuk mengakomodir kepentingan negaranegara anggota ASEAN. Cetak Biru AEC ini disetujui dan ditandatangani dalam KTT ASEAN Ke-13 di Singapura, bulan Nopember 2007.

Cetak Biru MEA yang merupakan rencana kerja strategis bagi negara-negara anggota ASEAN menuju terbentuknya integrasi

21 Departemen Perdagangan RI, Menuju ASEAN Economic Community 2015, Jakarta: Kemendag RI, 2009,hlm. 3. Budi Hermawan Bangun, Menuju Masyarakat Ekonomi ASEAN 2015: Aspek Regional ekonomi ASEAN memuat empat kerangka utama, yaitu:22

a. ASEAN sebagai pasar tunggal dan basis produksi internasional (arus perdagangan bebas untuk sektor barang, jasa, investasi, pekerja terampil, dan modal);

b. ASEAN sebagai kawasan regional ekonomi yang berdaya saing tinggi (regional competition policy, IPRs action plan, infrastructure development, ICT, energy cooperation, taxation, dan pengembangan UKM);

c. ASEAN sebagai suatu kawasan dengan pembangunan ekonomi yang merata (region of equitable economic development) melalui pengembangan UKM dan program-program initiative for ASEAN Integration (IAI); dan

d. ASEAN sebagai kawasan yang terintegrasi penuh dengan ekonomi global (pendekatan yang koheren dalam hubungan ekonomi eksternal serta mendorong keikutsertaan dalam global supply network).

Pelaksanaan rencana kerja strategis tersebut dijabarkan lebih lanjut melalui priority actions yang pencapaiannya dievaluasi dan dimonitor dengan menggunakan score card. Disamping itu, diperlukan dukungan berupa kemauan politik, koordinasi dan mobilisasi sumber daya, pengaturan pelaksanaan, peningkatan kemampuan (capacity building) dan penguatan institusi, serta peningkatan konsultasi antara pemerintah dan sektor swasta. Pelaksanaan rencana kerja strategis

22 Association of Southeast Asian Nations, ASEAN Economic Community Blueprint, Jakarta:ASEAN Secretariat, 2008,hlm. 6-26

\footnotetext{
dan Implikasinya terhadap Hukum Nasional Indonesia
} 
tersebut juga akan didukung dengan program pengembangan sumber daya manusia dan kegiatan penelitian serta pengembangan di masing-masing negara. ${ }^{23}$

\section{Implikasi Bagi Indonesia: Prospek dan Tantangan}

Terintegrasinya ekonomi di kawasan Asia Tenggara dengan disepakatinya MEA pada tahun 2015 mendatang sudah tentu membawa implikasi, baik secara langsung maupun tidak langsung, terhadap Indonesia. Dalam aspek hukum, implikasi ini terutama disebabkan Indonesia harus melaksanakan sejumlah kewajiban yang diminta oleh berbagai perjanjian kerjasama ASEAN di bidang ekonomi yang telah disepakati.

Secara formal, Indonesia telah meratifikasi hampir seluruh perjanjian-perjanjian tentang kerjasama ekonomi ASEAN, namun dalam praktiknya dapat saja timbul perbedaan antara ketentuanketentuan dalam perjanjian tersebut dengan ketentuan peraturan perundangan-undangan Indonesia. Jika hal ini terjadi maka Indonesia harus merubah ketentuanketentuan dalam hukum nasional Indonesia agar dapat lebih menyesuaikan dengan kesepakatankesepakatan di ASEAN. ${ }^{24}$

Implementasi perjanjian internasional ke dalam hukum nasional tidak terhenti sampai pada

\section{${ }^{23}$ Ibid.}

24 Livia Handria, Aspek-Aspek Hukum Internasional Pada Kerja Sama ASEAN di Bidang Ekonomi, Skripsi pada Fakultas Hukum Universitas Indonesia, Depok, 2009, hlm. 170.

Budi Hermawan Bangun, Menuju Masyarakat Ekonomi ASEAN 2015: Aspek Regional perumusan perjanjian internasional itu ke dalam hukum nasional, namun yang jauh lebih penting adalah bagaimana melaksanakan perjanjian-perjanjian kerjasama ekonomi tersebut. Bagi Indonesia, pelaksanaan perjanjian internasional tidaklah selalu mulus dan efektif karena berbagai hal.

Menghadapi MEA 2015, secara umum Indonesia masih mengalami beberapa masalah, misalnya: sumber daya manusia, pemenuhan stándar, daya saing rendah, dan infrastruktur yang kurang memadai. Masalah-masalah tersebut ditemui dalam lima pilar MEA, yaitu aliran barang, jasa, investasi, tenaga kerja terampil dan aliran modal secara bebas.

Pada sisi lain, pembentukan MEA 2015 membuka sejumlah peluang bagi Indonesia dalam meningkatkan sektor perekonomian nasional maupun posisi strategis Indonesia baik dalam lingkup intra ASEAN maupun ekstra ASEAN. ${ }^{25}$

Untuk memastikan bahwa MEA berjalan sesuai dengan apa yang telah dirancang dan Indonesia kemudian dapat meperoleh keuntungan dari MEA, tentu saja salah satu hal penting yang harus dilakukan oleh Indonesia adalah dengan melakukan berbagai pembaharuan hukum yang lebih berorientasi pada jaminan dan kepastian hukum sesuai dengan yang diinginkan dalam berbagai peraturan perjanjian kerjasama bidang ekonomi ASEAN tersebut.

25 Misly Harera, "Indonesia Menuju Kekuatan Ekonomi Kawasan Melalui Integrasi Ekonomi ASEAN: AEC 2015", Jurnal Online TransBORDER, Edisi 1 Vol. 1, Januari-Juni 2012, hlm. 193.

\footnotetext{
dan Implikasinya terhadap Hukum Nasional Indonesia
} 
Dengan target bahwa di tahun 2015 MEA mulai berjalan dan Indonesia akan mendapat manfaat dari hal itu, maka kontribusi positif hanya bisa didapatkan melalui sistem hukum dan kelembagaan yang memadai. ${ }^{26}$

Berkaitan dengan hal tersebut, Hart $^{27}$ mengatakan bahwa dengan memakai pendekatan hukum dalam pembangunan ekonomi, maka hukum harus mengandung unsurunsur sebagai berikut: Pertama, hukum harus dapat membuat prediksi (predictability), yaitu apakah hukum itu dapat memberikan jaminan dan kepastian hukum bagi pelaku dalam memprediksi kegiatan apa yang dilakukan untuk proyeksi pengembangan ekonomi. Kedua, hukum itu mempunyai kemampuan prosedural (procedural capability) dalam penyelesaian sengketa. Misalnya dalam mengatur peradilan tribunal (court or administrative tribunal), penyelesaian sengketa diluar pengadilan (alternative dispute resolution) dan penunjukan arbitrer konsiliasi (conciliation) dan lembaga-lembaga yang berfungsi sama dalam penyelesaian sengketa. Ketiga, pembuatan, pengkodifikasian hukum (codification of goals) oleh pembuat hukum bertujuan untuk pembangunan negara. Keempat, hukum itu setelah mempunyai

26 R. Winantyo, et. al., (eds.), Masyarakat Ekonomi ASEAN (MEA) 2015: Memperkuat Sinergi ASEAN di Tengah Kompetisi Global, Jakarta: Elex Media Komputindo, 2008, hlm. 217.

27 Dalam Bismar Nasution, "Implikasi AFTA Terhadap Kegiatan Investasi dan Hukum Investasi di Indonesia", Jurnal Hukum Bisnis. Vol. 22, Januari-Februari 2003,hlm. 48. keabsahan, agar mempunyai kemampuan maka harus dibuat pendidikannya (education) dan selanjutnya disosialisasikan. Kelima, hukum itu dapat berperan menciptakan keseimbangan (balance). Karena hal ini berkaitan dengan inisiatif pembangunan ekonomi. Keenam, hukum itu berperan dalam menentukan definisi dan status yang jelas (definition and clarity of status). Dalam hal ini hukum tersebut harus memberikan definisi dan status yang jelas mengenai segala sesuatu dari orang. Ketujuh, hukum itu harus dapat mengakomodasi (accomodation) keseimbangan, definisi dan status yang jelas bagi kepentingan inividu-individu atau kelompok-kelompok dalam masyarakat. Terakhir, tidak kalah pentingnya dan harus ada dalam pendekatan hukum sebagai dasarpembangunan adalah unsur stabilitas (stability).

\section{PENUTUP}

Perkembangan ASEAN dari "hanya" perkumpulan negaranegara di kawasan Asia Tenggara menuju pembentukan sebuah komunitas yang salah satunya adalah komunitas ekonomi (MEA) membawa konsekuensi dan implikasi terhadap pembaharuan hukum Indonesia.

Hal ini berarti bahwa dalam menghadapi MEA 2015, Indonesia tidak cukup hanya sekedar meratifikasi atau menyatakan diri terikat dengan segala macam perjanjian-perjanjian kerjasama bidang ekonomi ASEAN semata, namun perlu mempersiapkan secara seksama langkah-langkah internal dalam melaksanakan substansi dari perjanjian-perjanjian tersebut. 


\section{DAFTAR PUSTAKA}

Association of Southeast Asian Nations, 2008, ASEAN Economic Community Blueprint, Jakarta:ASEAN Secretariat.

Cipto, Bambang, 2007, Hubungan Internasional di Asia Tenggara, Yogyakarta: Pustaka Pelajar.

Departemen Perdagangan RI, 2009, Menuju ASEAN Economic Community 2015, Jakarta: Kemendag RI.

Frost, Frank, 2008, “ASEAN's Regional Cooperation and Multilateral Relations: Recent Development and Australia's Interests", Australian Parliament Research Paper.

Goh, Gillian, 2003, "The 'ASEAN Way': Non-Intervention and ASEAN's Role in Conflict Management", Stanford Journal of East Asian Affairs, Vol. 3 No. 1, (Spring).

Handria, Livia, 2009, Aspek-Aspek Hukum Internasional Pada Kerja Sama ASEAN di Bidang Ekonomi, Skripsi pada Fakultas Hukum Universitas Indonesia, Depok.

Harera, Misly, 2012, "Indonesia Menuju Kekuatan Ekonomi Kawasan Melalui Integrasi Ekonomi ASEAN: AEC 2015”, Jurnal Online
TransBORDER, Edisi 1 Vol. 1, Januari-Juni.

Nasution, Bismar, 2003, "Implikasi AFTA Terhadap Kegiatan Investasi dan Hukum Investasi di Indonesia", Jurnal Hukum Bisnis. Vol. 22, Januari-Februari.

Pangestu, Mari Elka, 2009, "Competitiveness Towards ASEAN Economic Community", Journal of Indonesian Economy and Business, Vol. 24 No. 1.

Pratomo, Eddy, 2009, "Prospek dan Tantangan Hukum Internasional di ASEAN dan Indonesia Pasca Piagam ASEAN dari Sisi Perjanjian Internasional", Jurnal Hukum No. 1 Vol. 16, Januari.

Putra, Hilton Tanaka, dan Eka An Aqimuddin, 2011, Mekanisme Penyelesaian Sengketa di ASEAN: Lembaga dan Proses, Yogyakarta: Graha Ilmu.

Soverino, Jr., Rodolfo C., 2002, ASEAN: Today and Tomorrow, Jakarta: ASEAN Secretariat.

Suryokusumo, Sumaryo, 1993, "Aspek Hukum Internasional dan Regional ASEAN Sehubungan Dengan AFTA", Jurnal Luar Negeri, No. 24.

Budi Hermawan Bangun, Menuju Masyarakat Ekonomi ASEAN 2015: Aspek Regional dan Implikasinya terhadap Hukum Nasional Indonesia 
Jurnal Penelitian Hukum

Winantyo, R., et. al., (eds.), 2008, Masyarakat Ekonomi ASEAN (MEA) 2015: Memperkuat Sinergi ASEAN di Tengah Kompetisi Global, Jakarta: Elex Media Komputindo.

$\begin{array}{lrr}\text { Winarno, Budi, } 2008 & \text { "Politik } \\ \begin{array}{l}\text { Regionalisme } \\ \text { Tantangan }\end{array} & \text { ASEAN } & \text { di } \\ \text { Tengah } & \text { Arus } & \text { Besar } \\ \text { Globalisasi", } & \text { Jurnal } & \text { Ilmu } \\ \text { Politik } & \text { Hubungan } \\ \text { Internasional } & \text { Spektrum, } \\ \text { Vol. 5, No. 2, Juni. }\end{array}$

Budi Hermawan Bangun, Menuju Masyarakat Ekonomi ASEAN 2015: Aspek Regional dan Implikasinya terhadap Hukum Nasional Indonesia 